\title{
DEGLACIATION IN THE CANTABRIAN MOUNTAINS: PATTERN AND EVOLUTION
}

\author{
E. SERRANO ${ }^{1 *}$, M. GÓMEZ-LENDE ${ }^{1}$, R. PELLITERO ${ }^{2}$, \\ J.J. GONZÁLEZ-TRUEBA ${ }^{3}$

\begin{abstract}
${ }^{1 *}$ Department of Geography, University of Valladolid, 47011 Valladolid, Spain. ${ }^{2}$ Department of Geography \& Environment, University of Aberdeen. United Kingdom.

${ }^{3}$ CIESE-C, University of Cantabria, Comillas, Spain.
\end{abstract}

\begin{abstract}
The last deglaciation of the Cantabrian Mountain began later than $30 \mathrm{ka}$ ago, after a local glacier maximum. After this glaciation a moderate glacier retreat occurred during a less cold period, followed by a new glacier advance that deposited moraines close to the maximum extension moraine complexes. This cold but very dry period occurred between $22-18 \mathrm{ka}$ and it was related to European LGM. Dating made during the last 12 years support a distinctive model of deglaciation history for the last glacial cycle, different to North European and analogous to NW Iberian Mountains and the Pyrenees. The most important deglaciation phase began after $18 \mathrm{ka}$, when ice disappeared of the lower massifs, icefields withdraw and the main tongue glaciers divided in minor tongues. From $\sim 14$ to $\sim 11 \mathrm{ka}$ a new cold period implied a glacier growth dominated by topoclimatic factors in the massifs above 2100. Only on the highest massifs glaciers developed in all orientations, together withrock glaciers established mainly to the North orientations. During the Holocene there are not evidences of glacial stages and the deglaciation was complete. Only four small glaciers were developed during the Little Ice Age in the Picos de Europa, disappearing at the end of the XIX century.
\end{abstract}

\section{Deglaciación en la Cordillera Cantábrica: modelo y evolución}

RESUMEN. La última deglaciación de la Cordillera Cantábrica comenzó hace menos de $30 \mathrm{ka}$, cuando se produjo un máximo glaciar local. Tras esta deglaciación se sucede un periodo menos frío que ocasiona un retroceso glaciar después del cual un nuevo avance de los glaciares generó formas y depósitos glaciares muy próximas a los complejos morrénicos de la fase anterior. Este es un periodo frío y seco acaecido entre $\sim 22$ y $18 \mathrm{ka}$ que se relaciona con el LGM europeo. Las dataciones realizadas durante los últimos doce años permiten establecer un modelo de deglaciación distinto al del norte de Europa, pero similar al de los Pirineos y las montañas del NW peninsular. La fase de deglaciación más importante tendrá lugar después de $18 \mathrm{ka}$, cuando los macizos menos altos quedan 
libres de hielo definitivamente, los icefields desaparecen y las lenguas glaciares de mayor tamaño se dividen y quedan alojadas en las porciones altas de los valles. De 14 a $\sim 11 \mathrm{ka}$ se registra un nuevo avance, la fase de altura, con desarrollo de glaciares por encima de los 2000 metros condicionados por los factores topoclimáticos. Sólo en los macizos más elevados los glaciares se ubican en cualquier orientación aunque sus dimensiones son reducidas. En este periodo se desarrollan numerosos glaciares rocosos, en su mayoría en orientaciones $N$. Durante el Holoceno no hay pruebas de avances glaciares y la deglaciación es completa en la Montaña Cantábrica. Sólo cuatro pequeños glaciares se forman durante la Pequeña Edad del Hielo en Picos de Europa, desaparecidos a finales del siglo XIX.

Key words: glaciations, deglaciation, Quaternary, Cantabrian Mountains.

Palabras clave: glaciarismo, deglaciación, Cuaternario, Cordillera Cantábrica.

Received 10 March 2015

Accepted 21 April 2015

*Corresponding author: Department of Geography, University of Valladolid, 47011 Valladolid, Spain. E-mail: serranoe@fyl.uva.es

\section{Introduction}

The Cantabrian Mountain was occupied by glaciers during the Upper Pleistocene, and glaciers had a significant effect on climate and human communities during the last glaciation. Many geomophologists have investigated the glacial history of the Cantabrian Mountains, being the early visits of Casiano del Prado or Albrecth Penck the ones that fostered interest in the region. Studies in the Picos de Europa and western area led to controversy over the development of small glaciers spread by several massifs, or a wider glaciation affecting all massifs. Later debate concerned the number of glaciations. First, two Quaternary glaciations -the poliglacial theory- were attributed to Riss and Würm (Penck, 1897; Obermaier, 1914; Saenz, 1935; Hernández-Pacheco, 1944, 1961; Nussbaum and Gigax, 1952; Lotze, 1962), and later only one and recent glaciation -the monoglacial theory- was deduced (Martínez de Pisón and Arenillas, 1979; Muñoz-Jiménez, 1980; Arenillas and Alonso-Otero, 1981; Alonso-Otero et al., 1982; Smart, 1986; AlonsoHerrero, 1987, 2002; Frochoso, 1990; Castañón and Frochoso, 1992; Ugarte, 1992; Gale and Hoare, 1997; Frochoso and Castañón, 1998; Serrano and González-Trueba, 2002; Serrano and Gutiérrez-Morillo, 2002; González-Trueba, 2007a, 2007b), all of them from sediments and morphostratigraphic analysis. Studies were based on morphosequences showing features of glaciers retreat. During the 70's and 80's contributions focused on the delimitation of the maximum ice extent. Retreat stages were established during the nineties and first years of 21st century but today there is a lack of continuous, well-dated, high-resolution records of the changes in environmental conditions during deglaciation. Only during the last decade absolute dating has been obtained and glacial stages, mainly the glacial maximum, are located in time. The deglaciation history of the Cantabrian 
Mountain is closely related to that of neighbouring Pyrenees, where an asynchroneity of maximum glacier advances related to the European glaciations was detected (Jalut et al., 1992; García-Ruiz et al., 2003, 2010, 2013; Delmas, 2005; González-Sampériz et al., 2006). Different authors have pointed that the maximum extent of the Pyrenean glaciers occurred before $30 \mathrm{ka}$ BP with a later, less extensive advance during the European coldest period around $20 \mathrm{ka}$ BP. The asynchroneity of the maximum advances have been explained by different regional responses to climatic forcing and by the southern latitudes of the Iberian Peninsula (González-Sampériz et al., 2006; Delmas et al., 2008; García-Ruiz et al., 2010, 2013; Serrano et al., 2013). The present day controversy is on the possible synchrony between the Iberian Peninsula and European LGM in the Pyrenees or the Central System (Pallás et al., 2007; Calvet et al., 2011; Palacios et al., 2011), although some recent dates suggest an early maximum also for the Central System (Domínguez-Villar et al., 2013) and different evolution models have been proposed for the Mediterranean area (Hughes et al., 2006, 2008), including older phases than the last glacial cycle.

The Cantabrian Mountain is located in a climatically sensitive geographic position between the Atlantic seacoast and the Mediterranean environment of the inner Iberian Peninsula. During Pleistocene this transitional environment was very important for glaciers development on the northern and southern sides. Changes in the position of the polar front during the last glacial cycle implied variations in extent and activity of glaciers in the Cantabrian Mountains. In this climatic context, the Pleistocene glaciation was limited to the highest massifs (Fig. 1), configuring individualized glacial units very close together. These were of small size compared with the large glaciers that developed towards the east in the Pyrenean or alpine chains, but in accordance with the size and distribution of the glaciers in the westernmost and southernmost mountains of the Iberian Peninsula.

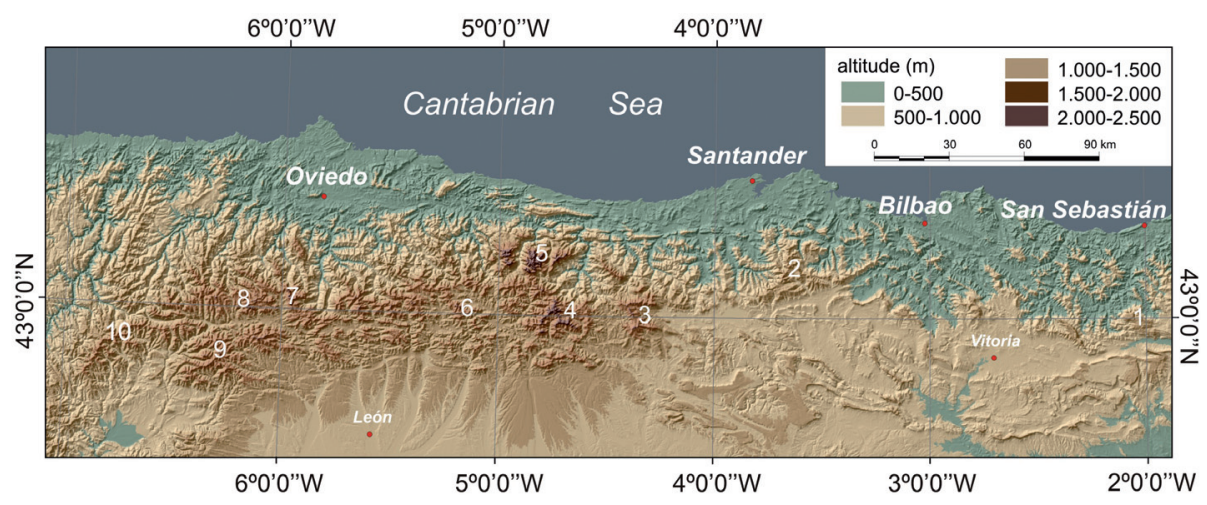

Figure 1. The Cantabrian Mountains and location of the highest massifs. 1: Aralar (1430 m a.s.l.). 2: Pas Mountain (1717 $m$ a.s.l.). 3: Alto Campoo-Valdecebollas (2174 $m$ a.s.l.). 4 : Fuentes Carrionas (2539 m a.s.l.). 5: Picos de Europa (2647 m a.s.l.). 6: Mampodre $(2192 \mathrm{~m}$ a.s.l.). 7: Peña Ubiña (2411 m a.s.l.). 8: Somiedo (2191 m a.s.l.). 9: Catoute (2112 m a.s.l.). 10 : Ancares (1992 m a.s.l.). 


\section{Geographical setting}

The Cantabrian Mountains, located in the Northern Iberian Peninsula, is a 450 $\mathrm{km}$ length mountain system between the Pyrenees and the Galician mountains (from $7^{\circ} 0^{\prime}$ to $2^{\circ} 0^{\prime} \mathrm{W}$ long. and $43^{\circ} \mathrm{N}$ lat.). The maximum altitude is located in the Picos de Europa massif, reaching 2648 m a.s.l. (Torrecerredo). The Cantabrian Mountains can be divided into two main geological units (Fig. 2) affecting the relief and glacial features:

- The western area is composed of the Ordovician and Carboniferous Asturian basement of slate, quartzite, limestone, sandstone and conglomerate. The complex structure, Paleozoic lithology and differential erosion, configures isolated massifs and ranges of moderate altitude individualized between lengthened depressions. Limestone, quartzite and sandstone shape positive and abrupt reliefs, and slate and turbidites, the depressions. The main massif is composed of Paleozoic limestone featuring alpine glaciokarstic reliefs (like Picos de Europa, Peña Ubiña, Espigüete) and sandstone relief (Fuentes Carrionas). On limestone massifs, the karstic landscape works together an important endokarstic network, where caves more than 1000 meters depth are common. Nowadays, some ice caves maintain metamorphic ice since Little Ice Age (Gómez Lende et al., 2014). To the north, the hydrography cuts the structures longitudinally, individualizing the massifs and generating high relief forms, whereas to the south it adapts to the structures.

- The eastern area, where altitudes are more moderate, is composed of Mesozoic outcrops and folded structures. The dominant rocks are Triassic sandstones and conglomerates, Jurassic and Cretaceous marl, sandstone, limestone and turbidites, and Tertiary terrestrial sedimentary rocks. Limestone spreads on the entire area and karstic landscapes are common. Endokarst has a limited depth but there are large horizontal cave systems. The incision of the Cantabrian rivers dissects the relief to the north, which develops deep valleys. To the southern side, the valleys are adapted to the folded structures.

The Cantabrian Mountain is exposed to the Polar Front, and its relative height and proximity to the sea (30 km aprox. to Cantabrian sea) determine the climatic conditions. The north-facing side has a hyperhumid oceanic mountain environment with a mean annual precipitation exceeding $2500 \mathrm{~mm} / \mathrm{year}$, whilst in the southfacing slope the climate is transitional Atlantic-Mediterranean, with precipitation ranging between 600-800 and 1800-2000 $\mathrm{mm}$ year $^{-1}$. Thus, the Cantabrian Mountains are an important fluvial and environmental threshold between the Atlantic and Mediterranean basins. 


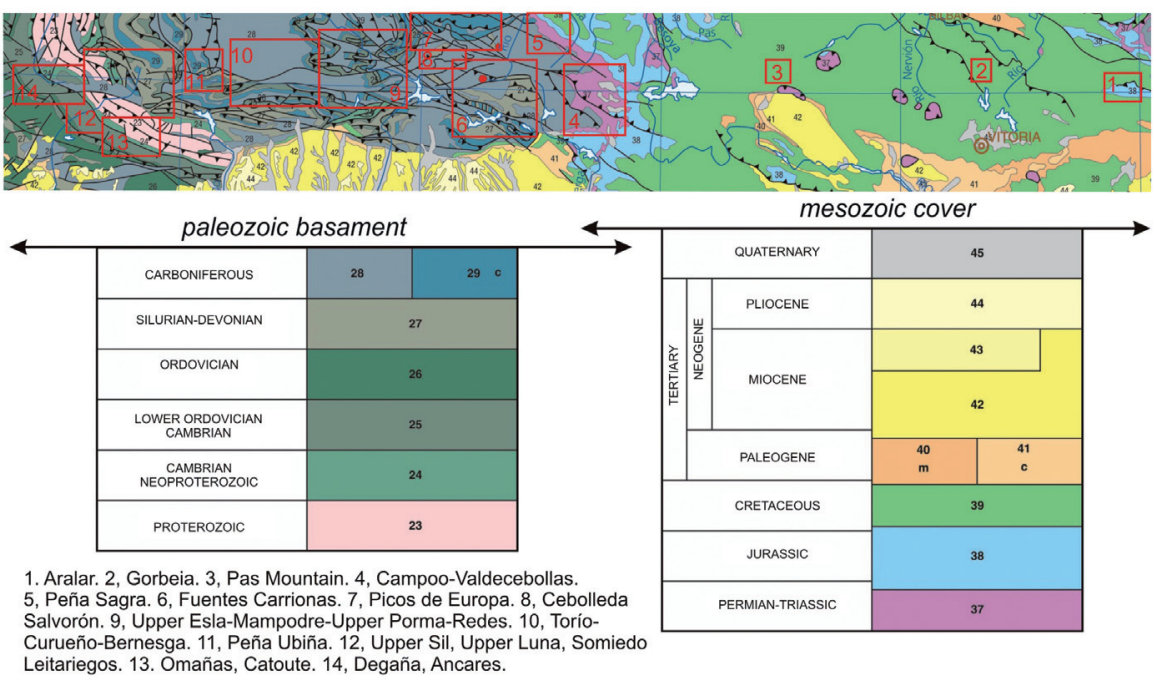

Figure 2. Geological sketch of the Cantabrian Mountain with location of the main glaciated areas.

Glacial morphology dominates all summits above $1900 \mathrm{~m}$ a.s.l., with a progressive lower altitude imprint up to $1300 \mathrm{~m}$ high on the divides of westernmost side of the range. Glacial morphology in the Cantabrian Mountain corresponds to highly varied glacial systems, like cirque glaciers with moraines forming small frontal arcs, large glaciated valleys with tongues few $\mathrm{km}$. long, and several large icefields fed by the Atlantic snowfalls, with outlets between 16 and $51 \mathrm{~km}$ long. Glacier fronts reached 400-600 $\mathrm{m}$ a.s.l. in the Northern side and 700 to $900 \mathrm{~m}$ in the south side.

\section{Landforms and mapping of glacial features}

The glacial morphology of the Cantabrian Mountain occupies nearly all summit areas of the so-called "Asturian Massif", while is less developed in the Eastern part of the range. Cirque glaciers appear located close to divides of moderate altitude (1200-1400 m) on the western side, and were also frequent in recession stages in the higher summits of the Main Divide. Glaciated valleys with tongues from $5 \mathrm{~km}$ to $15 \mathrm{~km}$ long occupy the upper valleys in the area between Ancares to Campoo. Icefields have been clearly interpreted in the Picos de Europa, Pas Mountain, Aralar, Sil Valley and Upper Esla, formed after a broad extension of the accumulation areas. Nevertheless, it is not possible to find erosional features like cirques and over-deepened basins in the areas that were occupied by the icefields, although there are relevant glacial troughs reaching moderate altitudes in the south side (750 $\mathrm{m}$ a.s.l.). Icefield outlets also deposited lateral and frontal moraine complexes. Table 1 shows the morphological characteristics of the main massifs in the Cantabrian Mountains at different stages. LIA moraines are not included in the Table because the historical glaciation was generated once the deglaciation completed, and a limited ice growth in the highest cirques of Picos de Europa occurred (González-Trueba, 2006, 2007; González-Trueba et al., 2008). 
N\&年:

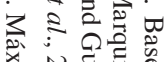

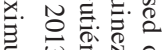

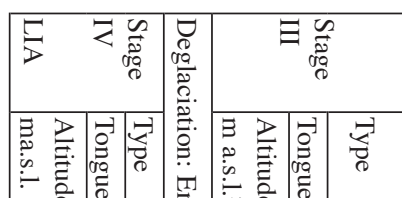

$\pi \stackrel{2}{2}$

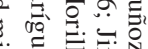

ㄹ. 일.

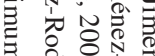

1

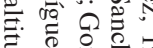

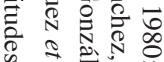

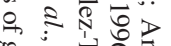

\%

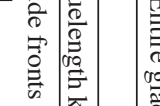

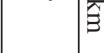

年

政

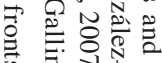

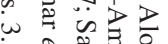

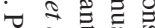

० 0 के

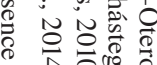

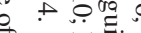

$\begin{array}{lll}\rightarrow & \pi & 0 \\ 0 & 0 & 0\end{array}$

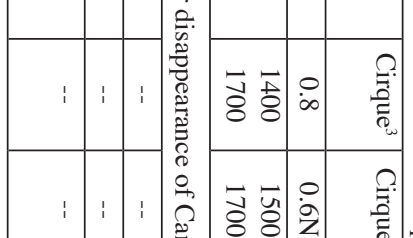

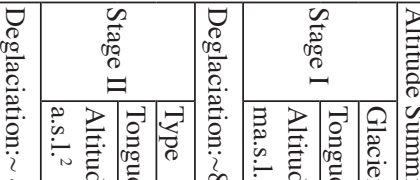

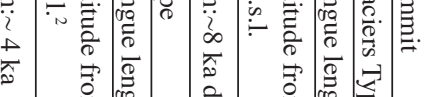

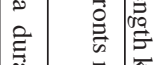

苞.

19

ڤั.

N

$\therefore$ N

泀

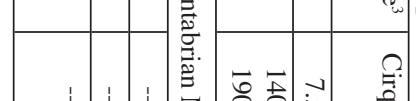

B $\overline{\mathrm{B}}$

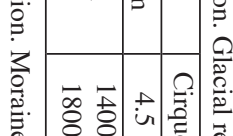

站

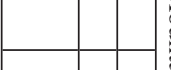

言.

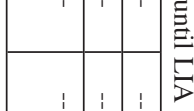

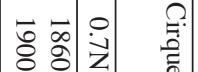

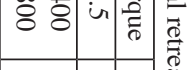

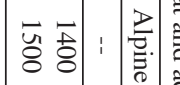

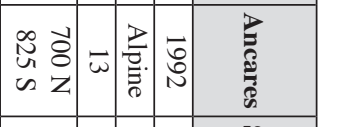

$\frac{2}{2}$

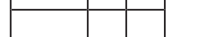

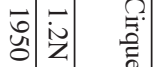

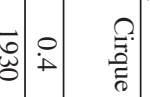

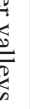

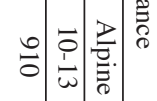

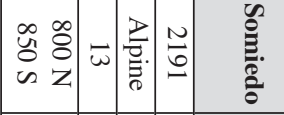

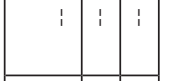

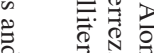

$\frac{n}{8}$

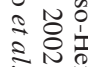

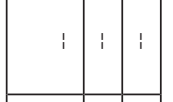

< 4

응

宛

ก. $₫$

ํㅡㄹํำ

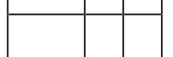

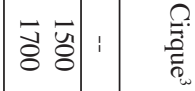

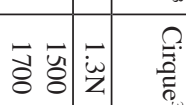

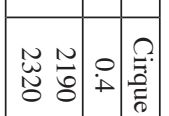

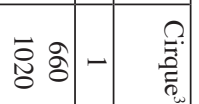

-

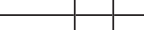

ये

范

을.

N.

눙용

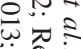

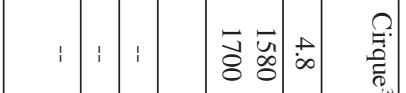

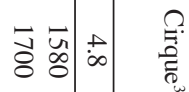

岁 స్⿱

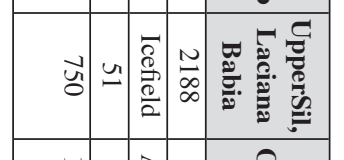

$\frac{2}{\frac{2}{2}}$

은

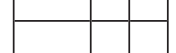

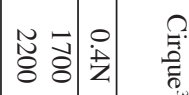

峁

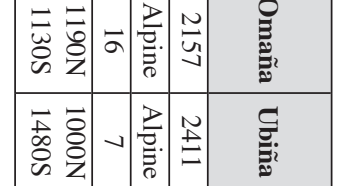

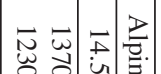

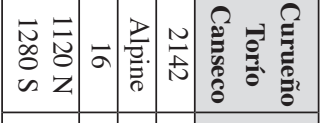

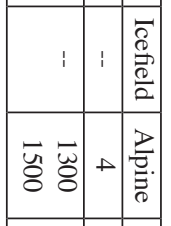

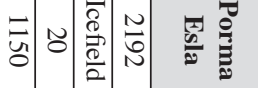

ช̆ㅇด

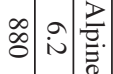

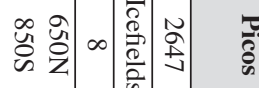

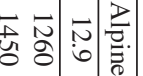

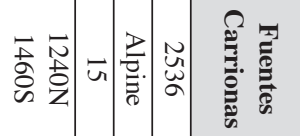

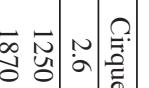

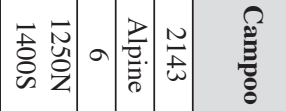

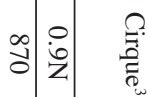

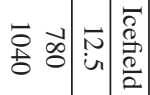

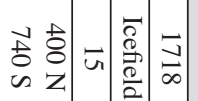

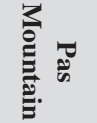

눙

웅

in

吾产

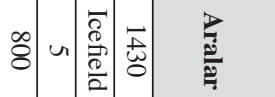




\section{Dating and deglaciation pattern}

The maximum extent of glaciers in the Cantabrian Mountains corresponded to the development of icefields -Pas, Aralar, Picos de Europa, Upper Porma-Redes, Upper SilBabia-; alpine glaciers -Cebolleda, Fuentes Carrionas, Ancares, Omañas, Solvorón, Campoo-; and cirque glaciers -Valdecebollas, Peña Sagra, Gorbeia, Pajares-. Recent studies on distinct Cantabrian Mountain massifs have provided radiocarbon dates $\left({ }^{14} \mathrm{C}\right.$, AMS) in Redes, Sil Valley, Picos de Europa and Pas Mountains (Jiménez-Sánchez and Farias, 2002; Jiménez-Sánchez et al., 2013; Jalut et al., 2010; Moreno et al., 2010; Serrano et al., 2011, 2012, Niewendam et al., 2015), and U/Th and optically stimulated luminescence (OSL) dates from the Fuentes Carrionas and Pas Mountains (Pellitero, 2011, 2014; Serrano et al., 2012; Frochoso et al., 2013). The glacial morphosequences analysed and available dates have facilitated a first approximation to the Late Pleistocene glacial chronology and deglaciation pattern in the Cantabrian Mountains, where three main Pleistocene glacial phases have been detected (Jiménez-Sánchez et al., 2013; Serrano et al., 2013a,b; Rodríguez-Rodríguez et al., 2014).

Dates (table 2) for the maximal extent of glaciers show ages between $44.9 \mathrm{ka}$ and $28.9 \mathrm{ka}$ in six cases, 4 by ${ }^{14} \mathrm{C}$ and 2 by OSL. In the Picos de Europa the maximum glacial extent has been dated as previous to $40 \mathrm{kyr}$ in Enol (Moreno et al., 2010), 40,480 \pm 820 BP in Comeya (Jiménez-Sánchezand Farias, 2002), 35,700-34,850 cal yr BP in the Duje valley (Serrano et al., 2012) and $37.2 \mathrm{kyr}$ cal BP in the Belbin basin (Nieuwendam et al., 2015). The minimum age obtained for the glacial maximum in the Fuentes Carrionas massifs is 36,028 $\pm 2350 \mathrm{yr}$ BP (Pellitero, 2011, 2014; Serrano et al., 2012) and in the TruebaValley (Pas Mountains) the age is prior to 29,149-28,572 cal yr BP (Serrano et al., 2012, 2013) and 44,980 $\pm 2300 \mathrm{yr}$ BP (Frochoso et al., 2013) on the north side. The western massif shows the same chronologies: 28,990 $\pm 230 \mathrm{yr}$ BP in Redes (Jiménez et al., 2002, 2013) and around $44 \mathrm{kyr}$ in the Sil Valley (Jalut et al., 2010). All dates, obtained from different deposits (lacustrine, peat bog and till) and using distinct techniques (AMS and OSL) confirm the maximum extent of glaciers during the MIS3. The sedimentary sequence of Belbín shows a coetaneous intense periglacial activity in the region, with deposition of colluviums between 37.2 and 29 cal kyr BP (Nieuwendam et al., 2015). Thus, the first glacial stage seems to have behaved differently compared to northern Europe glacial maximum, during a cold and wet environment related to cold and humid masses that came from the N, NW and SW, when the jet stream was located at lower latitudes.

After $35-29 \mathrm{ka}$ BP there was a brief glacial retreat. Glacier fronts moved away from the frontal moraine complexes. Over-deepened basins were occupied with proglacial lakes, and proglacial complexes developed in the lower sectors of glacial troughs. The entity of deglaciation between glacial stages I and II is not known yet, although González-Sampériz et al. (2006) suggested an important reduction of the ice tongues in the Pyrenees. 
Table 2. Dating of the glacial maximum in the Cantabrian Mountains.

\begin{tabular}{|c|c|c|c|c|c|c|c|}
\hline Place & Site & Tecnique & Sediment & $\begin{array}{c}\text { Depth } \\
\text { (m) }\end{array}$ & $\begin{array}{c}{ }^{14} \text { C Age yr BP } \\
\text { OSL age } \\
\text { U/Th age }\end{array}$ & $\begin{array}{c}\text { Ages cal } \\
\text { yr BP }\end{array}$ & Ref. \\
\hline \multirow{6}{*}{$\begin{array}{l}\text { Picosde } \\
\text { Europa }\end{array}$} & Áliva & AMS & Lacustrine & 15.50 & $31,200+/-440$ & $35,700-34,850$ & 1 \\
\hline & \multirow{2}{*}{ Comeya } & AMS & Lacustrine & 35.5 & $40,480 \pm 820$ & $43,230-45,000$ & 2 \\
\hline & & OSL & Glaciofluvial sand & 42,7 & $45,000 \pm 330$ & ---- & 3 \\
\hline & \multirow{2}{*}{ Enol } & AMS & $\begin{array}{l}\text { Lacustrine } \\
\end{array}$ & 4.39 & $36,200+1100$ & $40,023-42,250$ & \\
\hline & & AMS & Lacustrine & 5.30 & $32,500+500$ & $37,065-38,689$ & 4 \\
\hline & Belbín & AMS & Bulksediment & 5,39 & $32,530 \pm 430$ & $36,718 \pm 1203$ & 5 \\
\hline \multirow{6}{*}{$\begin{array}{c}\text { Pas } \\
\text { Mountain }\end{array}$} & Trueba & AMS & Peat & 1 & $26,082+/-118$ & 30,676-31,348 & 6 \\
\hline & Soba valley & OSL & Till & 3.5 & $44,98 \pm 2,3$ & -- & \\
\hline & \multirow{4}{*}{ Altos Asón } & OSL & Till & 2.5 & $40,43 \pm 5,14$ & -- & \\
\hline & & OSL & Till & 5 & $64,600+510$ & -- & \\
\hline & & OSL & Till & 6.5 & $75,100+520$ & -- & \\
\hline & & OSL & Till & 9.5 & $78,500+720$ & -- & 7 \\
\hline $\begin{array}{c}\text { Fuentes } \\
\text { Carrionas }\end{array}$ & $\begin{array}{l}\text { Vega de } \\
\text { Naranco }\end{array}$ & OSL & Supraglacial & 0.50 & $36,028 \pm 2350$ & -- & 8 \\
\hline \multirow{3}{*}{ Upper Sil } & \multirow{2}{*}{ Castro lake } & AMS & Pollen & 7.81 & $39,300+1000$ & $42,605-44,190$ & \\
\hline & & AMS & Sandy clay & 8.85 & $34,000+1400$ & $36,843-40,523$ & \\
\hline & La Mata & AMS & Clay & 5.22 & $>35,000$ & ---- & 9 \\
\hline \multirow{3}{*}{$\begin{array}{l}\text { Redes } \\
\text { Natural } \\
\text { Park }\end{array}$} & \multirow{2}{*}{ Monasterio } & ${ }^{14} \mathrm{C}$ & Lacustrine clastic & 35.6 & $28,990 \pm 230$ & $33,123-33,847$ & 10 \\
\hline & & OSL & Till & 2.30 & $24,000 \pm 180$ & --- & \multirow{2}{*}{3} \\
\hline & Tarna Valley & OSL & Lacustrine & 42 & $44,966 \pm 3337$ & --- & \\
\hline
\end{tabular}

1, Serrano et al., 2012. 2, Jiménez-Sánchez and Farias, 2002. 3, Jiménez Sánchez et al., 2013. 4, Moreno et al., 2010. 5, Nieuwendam et al., 2015. 6, Serrano et al., 2013. 7, Frochoso et al., 2013. 8, Pellitero, 2011. 9, Jalut et al., 2010.

A second glacial stage was established from sedimentological and geomorphological features. The varied lithological composition of the moraines at Vega del Naranco (Fuentes Carrionas, Fig. 3), the two infill deposits in the Trueba Valley (Pas Mountain), and the changing directions of glacial flows in the Picos de Europa show a glacial retreat and re-advance to positions very close to the previous stage (Turú et al., 2007; Pellitero, 2011; Serrano et al., 2012, 2013). This stage can be correlated with a second stage of deglaciation dated in the Alto Nalón at 20.6 kyr BP (Jiménez-Sánchez et al., 2002) and in Enol lake between 20 and $18 \mathrm{ka}$ (Moreno et al., 2010). A minimum lost on ignition (LOI) in the lacustrine sediments of Áliva, dated between 21,500-21,390 cal yr BP, and the cooling detected between 22.0 and $17.7 \mathrm{kyr}$ cal BP in the Belbin Depression (Nieuwendam et al., 2015) are consistent with Nalón and Enol dates, and all point to a cold period with a second advance.

Deglaciation between stages II and III brought the individualization of large icefields into smaller and individual glacial tongues in the tributary valleys, which can be tracked by the disjunction moraines (Pérez-Alberti et al., 2002; González-Gutiérrez, 2002; Santos, 2010; Pellitero, 2012, 2014; Santos et al., 2013). Dissociation dynamics during 
deglaciation have been pointed in Picos de Europa, Pas Mountain, Ancares, Alto Sil, Curueño and Fuentes Carrionas. Most of the glaciers had fronts situated above $1600 \mathrm{~m}$ and $1700 \mathrm{~m}$ a.s.l., which means a massive deglaciation in the lowest, westernmost part of the range (table 1 and 3 ).

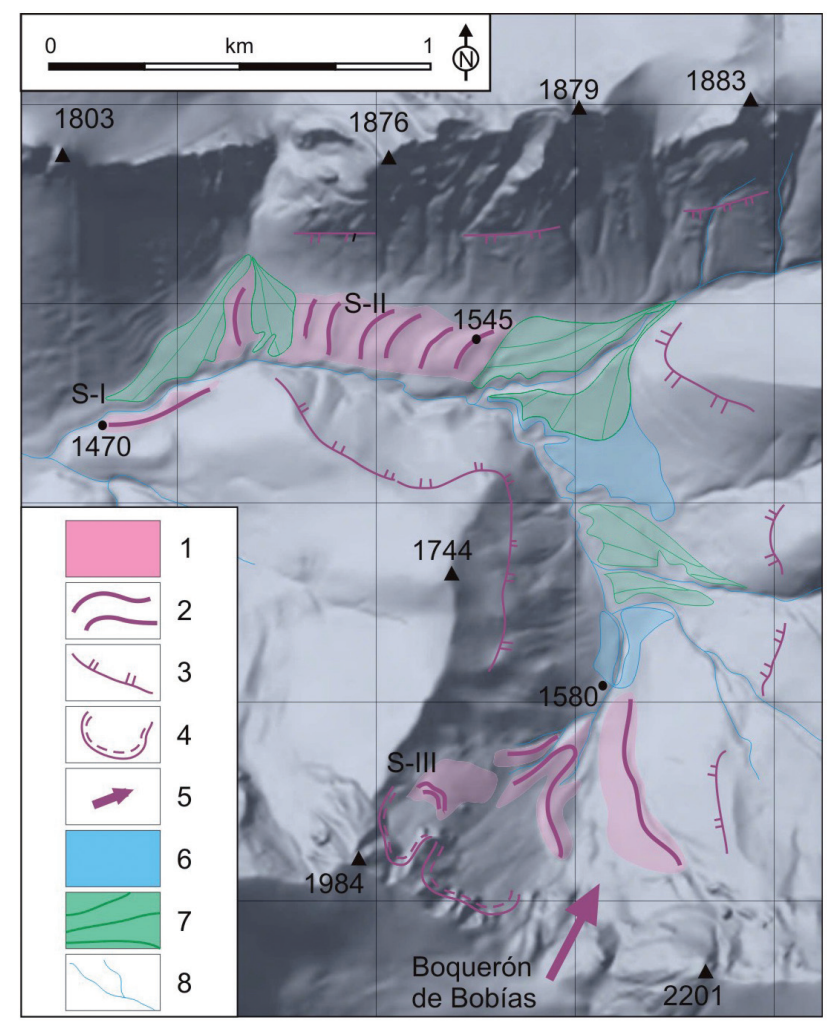

Figure 3. Glaciomorphological sketch of Vega de Naranco Valley (Fuentes Carrionas, León). The representative frontal moraine complex shows the glacial stages (S-I, S-II and S-III) represented in the valley (Modified from Pellitero, 2012).

Moraines located in the vicinity of high cirques above 1800-2000 m a.s.1. indicate the existence of an "altitude stage" (stage III), mapped in all massifs around 2000 (Fig. 3). This stage is characterised by short valley and cirque glaciers situated above all on north-facing slopes. Sil valley, Omañas, Babia valley, Upper Porma and Curueño, Peña Ubiña, Mampodre, Fuentes Carrionas, Alto Campoo-Valdecebollas (Fig. 4), Peña Sagra and Picos de Europa would have kept glaciers from this stage. Well-preserved moraine complexes are very frequent and point to a period of equilibrium and minor advance. The largest glaciers at this stage were located in Picos de Europa and Fuentes Carrionas, where two different pulsations have been established (González-Trueba, 2007, Pellitero, 2013). Glaciers developed nearby rock glaciers, mainly on north-facing slopes in massifs with summits around 2000 
metres. The lowest massifs in the eastern and western sectors would be definitively deglaciated (Ancares, Laciana, Gorbeia, Aralar).
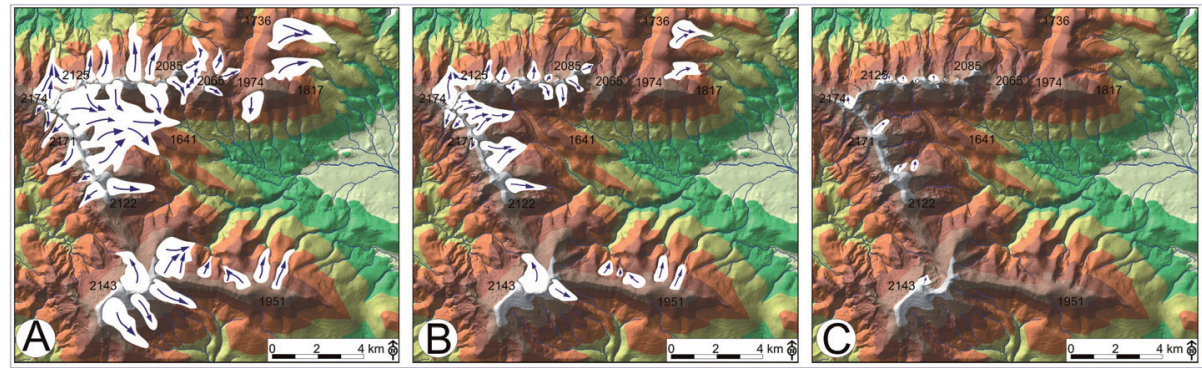

Figure 4. Glacial evolution in the Alto Campoo-Valdecebollas massifs. A: Stage I, with development of tongue glaciers. B: Stage II, small tongue glaciers, mainly in the north facing cirques and slopes. C: Stage III. Only small cirque glaciers oriented to the north are located under the highest peaks.

The formation of rock glaciers was common across the range during this stage, with up to 160 relict rock glaciers inventoried (Redondo et al., 2010; Gómez-Villar et al., 2011; Pellitero et al., 2011). Rock glaciers are located preferentially to the west of the Porma valley, including Redes, San Isidro, Curueño, Upper Luna, Somiedo, Laciana, Upper Sil, Omañas, Degaña and Ancares, with a $73 \%$ of the entire rock glacier population. Rock glaciers are indicators of permafrost environments, although their altitudinal distribution and preferential north orientation (100\% between NW and NE, and $70 \%$ in north orientation) limit the permafrost environment to the highest portion of cirques in north-faced slopes. This is also related to the larger availability of debris in the more heavily glaciated, eroded -and therefore steeper- north-facing cirques. The high presence of rock glaciers to the west could be related to the moderate altitude of summits, all of them lower than $2200 \mathrm{~m}$, allowing a wide periglacial environment. These facts are consistent with the development of rock glacier in the lowest glaciated massifs in the central and Eastern Cantabrian Mountain, such as Cebolleda, Peña Ten, Mampodre or Peña Sagra.

This period has a high degree of uncertainty because no dating has been made on moraines or lacustrine deposits related to the cirque moraines, and chronologies are based on indirect data. Only three evidences of the occurrence of a cold period can be correlated with the highest moraines, all of them in the Picos de Europa: (i) In the lacustrine deposits of Enol, Moreno et al. $(2010,2011)$ have detected equilibrium in the Ca content between 14.5 and $13.5 \mathrm{ka}$ and a cooling between 13.5-11.6 cal ka BP, indicating a cold and dry phase endorsed to the Younger Dryas. (ii) Serrano et al. (2012) recorded a moderate minimum LOI in the lacustrine sediments of Áliva ca. 13.9 cal ka BP, also interpreted as a climatic cooling. (iii) Finally, a cold period has been recorded between 13 and $8.1 \mathrm{cal} \mathrm{ka} \mathrm{BP}$ in the lacustrine sediments of Belbin depression (Nieuwendam et al., 2015). 
Table 3. Synthesis of glacial and deglaciation stages in the Cantabrian Mountains.

\begin{tabular}{|c|c|c|c|c|c|c|}
\hline Era & Stage & $\begin{array}{l}\text { Morphostratrigraphic } \\
\text { Name }\end{array}$ & $\underset{*}{\text { MIS }}$ & $\begin{array}{c}\text { Peaks } \\
\text { ma.s.l. } \\
* *\end{array}$ & $\begin{array}{l}\text { Glaciated } \\
\text { Massifs }\end{array}$ & $\begin{array}{l}\text { Glacial } \\
\text { period }\end{array}$ \\
\hline \multirow{2}{*}{ Holocene } & IV & Cirque glaciers, L.I.A. & \multirow{2}{*}{ MIS 1} & $>2600$ & Picos de Europa & Historical \\
\hline & & Postglacial & & \multirow{2}{*}{\multicolumn{2}{|c|}{$\begin{array}{c}\text { DEGLACIATION } \\
\text { Definitive ice free massifs }\end{array}$}} & Postglacial \\
\hline \multirow{9}{*}{ Pleistocene } & & DEGLACIATION & \multirow{6}{*}{ MIS 2} & & & \multirow{3}{*}{ Lateglacial } \\
\hline & IIIb & $\begin{array}{l}\text { Confined glacial } \\
\text { cirques }\end{array}$ & & $>2140$ & $\begin{array}{l}\text { Gistredo, Ubiña, } \\
\text { Esla, Picos, } \\
\text { Cebolleda, } \\
\text { Salvorón, Fuentes } \\
\text { Carrionas }\end{array}$ & \\
\hline & IIIIa & $\begin{array}{l}\text { Altitude stage } \\
\text { Glacial Advance and } \\
\text { Equilibrium } \\
\text { Rock glaciers }\end{array}$ & & $>2040$ & $\begin{array}{l}\text { Ancares, Gistredo, } \\
\text { Somiedo, Sil, Esla, } \\
\text { Omañas, Ubiña, } \\
\text { Picos, Cebolleda, } \\
\text { Salvorón, Fuentes } \\
\text { Carrionas, Campoo } \\
\end{array}$ & \\
\hline & \multicolumn{2}{|c|}{ DEGLACIATION } & & \multicolumn{2}{|c|}{$\begin{array}{c}\text { DEGLACIATION } \\
\text { Most massif are glaciers free }\end{array}$} & \multirow[b]{2}{*}{ Finiglacial } \\
\hline & \multicolumn{2}{|c|}{$\begin{array}{l}\text { DEGLACIATION } \\
\text { Minor Glacier advances and } \\
\text { Equilibrium (Disjunction } \\
\text { phase) }\end{array}$} & & $>1750$ & $\begin{array}{l}\text { Ubiña, Esla, } \\
\text { Curueño, Picos, } \\
\text { Cebolleda, } \\
\text { Salvorón, Fuentes } \\
\text { Carrionas, Campoo }\end{array}$ & \\
\hline & II & Glacial Advance & & $>1430$ & All massifs & \multirow{3}{*}{$\begin{array}{l}\text { Last } \\
\text { Glacial } \\
\text { Cycle }\end{array}$} \\
\hline & \multicolumn{2}{|r|}{ DEGLACIATION } & & \multicolumn{2}{|c|}{ DEGLACIATION } & \\
\hline & $\mathrm{I}$ & $\begin{array}{l}\text { Local Glacial } \\
\text { Maximum }\end{array}$ & MIS 3 & $>1430$ & All massifs & \\
\hline & 0 & Pre- Maximum & $\begin{array}{l}\text { MIS } \\
12 \\
\text { MIS } \\
22\end{array}$ & $>2100$ & $\begin{array}{l}\text { Sil, Degaña, Redes, } \\
\text { Picos, Fuentes } \\
\text { Carrionas }\end{array}$ & $\begin{array}{l}\text { Pre-Last } \\
\text { Glacial } \\
\text { Cycle }\end{array}$ \\
\hline
\end{tabular}

* Marine Isotopic Stadium. ** Maximum altitude of summits of glaciated massifs.

\section{Deglaciation and climate evolution in Cantabrian Mountains}

Partial deglaciation of Cantabrian Mountain occurred after 35-29 ka BP, when glaciers retreated in Picos de Europa, Sil and Redes massifs. The basal age of deposits of Enol ( 40 ka), Villaseca and La Mata ( 44 ka), Áliva ( 35 ka), Belbín ( 37 ka), Espinosa de los Monteros ( $29 \mathrm{ka})$ and Asón ( $44 \mathrm{ka})$ confirm that the last deglaciation occurred at the same time that in the Pyrenees, and earlier than in northern latitudes of Europe, an 
important fact for animal and human occupation of Cantabrian Mountains (Álvarez-Lao and García, 2011; Serrano et al., 2015). So, after 35 ka a deglaciation period began on the Cantabrian Mountains.

From 50 to $30 \mathrm{ka}$ ago cold-adapted large mammals occupied the entire Iberian Peninsula, with amaximum spread between 42 and 31 cal ka BP, including Northern Cantabrian side (Álvarez-Lao and García, 2010, 2011). The same authors show that between 30 and $20 \mathrm{ka}$ the cold fauna was dramatically reduced and only Mammuthus primigenius appears in one site in the Cantabrian Coast. After glacial stage I, in the Enol and Belbin depressions, just $2.5 \mathrm{~km}$ away, the deglaciation processes generated a high production and redistribution of sediment, similar to what happened in the Duje valley, where an increase of organic matter is detected (Moreno et al., 2011; Serrano et al., 2012; Nieuwendam et al. 2015). Dryness could be responsible for the retreat of the glaciers between 26 and $20 \mathrm{ka}$ (Moreno et al., 2010). A high frequency of freeze-thaw cycles, frost weathering and high moisture content during an extended cold period has been deduced from angular grains and sharp features of the silty deposit (Nieuwendam et al., 2015). As we mentioned above, the entity of glacier retreat is unknown, and although in the Pyrenees could have been very intense (Gonzalez-Sampériz et al., 2006), various facts point to not very cold conditions with periglacial environment in the high mountain.

Sedimentological, palynological and geomorphological evidences indicate a cold phase and a new episode of glacial readvance, glacial stage II, between 21 and $18 \mathrm{ka}$ in the Picos de Europa and between 23 and $19 \mathrm{ka}$ in the whole Cantabrian Mountains (Jiménez-Sánchez and Farias, 2002; Jiménez-Sánchez et al., 2013; Serrano et al., 2012, 2013; Rodríguez-Rodríguez et al., 2014). The second stage have been characterised by a small reduction in the extent of glaciers, resulting in shorter and thicker glaciers, although with an increase in volume in the frontal portions (Serrano et al., 2012, 2013, 2015). Cold-adapted large mammals were detected again in the Cantabrian Coast after $25 \mathrm{ka}$ (Álvarez-Lao and García, 2011) and the environmental conditions could be characterised by a cold, dry and more stable climate with glaciers fed by snowfalls from cold, dry air masses from the N and NW, and could be coetaneous with the European LGM. On the basis of the small-mammal assemblages in archaeological sites, Carrión et al. (2012) showed that the climatic conditions, which are evident in the rest of Europe, are not detected in Cantabrian sites between 20 and $17.8 \mathrm{ka}$ ago, although the mean annual temperatures were lower than today and the environment was dominated by wet open meadows.

A new deglaciation period began after $\sim 18 \mathrm{ka}$ when glaciers retreated to the upper cirques and troughs. The Valle glacial cirque (Somiedo Valley) was free of ice around $17.5 \pm 0.3$ cal kyr BP, when the sedimentation of lacustrine deposits begun (Allen et al., 1996). Similarly, a warmer period was identified in Belbin depression between $\sim 17.4$ and 13.4 cal kyr BP. Jalut et al. (2010) detected in the Pyrenees a deglaciation phase between 15 and $13.3 \mathrm{kyr}$, and Palacios et al. (2015) between 16 and $11 \mathrm{kyr}$, all of them consistent with the timeline in the Cantabrian Mountain. A substantial deglaciation could affect to all massifs of Cantabrian Mountain, and periglacial and permafrost environments 
occupied the highest ranges. During deglaciation, glacier tongues were divided into smaller tongues staying in the upper valleys above 1600 and $1700 \mathrm{~m}$ a.s.l.

During the last glacial advance in most Cantabrian massifs, the "altitude stage", the development of glaciers and rock glaciers were determined by topoclimatic factors. Although in the Pyrenees it has been pointed the hypothesis that small glaciers and rock glaciers developed close to the cirque headwalls could correspond to the last phase of glacial decay (Palacios et al. 2015), we think that a new cold phase permitted the growth of glaciers and the existence of periglacial conditions. Intense cold permitted the genesis of rock glaciers, always northern-oriented, although snowfalls were not enough for the development of large glaciers. Frontal moraine complexes and rock glaciers are spread on many cirques, creating a typical landscape on all massifs above 2000 meters. This stage has been related with the Younger Dryas event, well characterized as a cold and arid phase in the Enol lake sequence between 14.5 and $11.6 \mathrm{ka}$ (Moreno et al., 2010, 2011). Since $13.5 \mathrm{ka}$ BP the Enol Lake shows a low lacustrine productivity and low carbonate content, which is interpreted as a response to colder temperatures and decrease in rainfall (Moreno et al., 2011). Younger Dryas (YD) in the NW of the Iberian Peninsula has been defined as a cold and dry period from sea cores (Martrat et al., 2007; Vegas et al., 2013; Salgueiro et al., 2014), analysis of speleothems (Stoll et al., 2014; Morales-Molino and García-Antón, 2014) and palynological records (Naughton et al., 2007; Jalut et al., 2010). Also, the organic content decreased in proglacial sediments of Picos de Europa (Moreno et al., 2010; Serrano et al., 2013). Although in the Enol lake there was not significant changes in the sedimentological and geochemical values, the low in-lake productivity between 12.7-11.6 cal ka BP points to an abrupt cooling disturbing all basin (Moreno et al., 2010). These authors have interpreted an interruption in sedimentation of Enol Lake during the Younger Dryas as a frozen period of the lake, although this period was not long enough to result in a substantial glacier re-advance. Therefore, environmental changes could not to be as dramatic as they were in previous stages in Cantabrian Mountains, such that glacial advances and permafrost environments were only possible in the highest altitudes.

Post Younger Dryas climate changed to warmer conditions, as observed in Enol records (Moreno et al., 2011). According to archaeological data, a humid phase began between 12-7 cal ka BP, with a thermal optimum around 9 ka (Pérez-Obiol et al., 2011; Naughton et al., 2007). Since 11.6 ka onwards an increase of carbonates and organic matter was registered in Enol Lake, which is interpreted as an increase in rainfall, consistent with the warmer and wetter conditions in NW Iberian Peninsula (MuñozSobrino et al., 2001; Naughton et al., 2007). Cantabrian Mountain possibly was free of ice in the Early Holocene, between 11.5 and $9 \mathrm{ka} \mathrm{BP}$, and no evidences of Holocene glacial advances exist nowadays. The 8.2 event and cooling and drier conditions deduced from palinological proxies (Muñoz-Sobrino et al., 2004, 2007, Pérez-Obiol et al., 2011) does not seem to be reflected in the glacial record.

The last glacial advance, located only in the Picos de Europa, has been well defined by glacial features and historical documents as a $1^{\circ} \mathrm{C}$ cooling (González-Trueba, 2006, 2007) that finished at the end of XIX century, when glaciers turned into icepatches 
(Serrano et al., 2011). Pollen records cannot mark this change because of the intense landscape transformation and territory over-exploitation in the preceding centuries (Muñoz-Sobrino et al., 2005), although in some Pyrenean lake deposits the Little Ice Age has been tracked to colder and more humid conditions, showing a strong link between periods of more positive water balance and phases of reduced solar activity (Morellón et al., 2009, 2012).

Compared to global reconstruction of glaciers and climate, the deglaciation model proposed shows a maximum previous to European LGM, as pointed by several authors (Jiménez-Sánchezand Farias, 2002; Moreno et al., 2010; Jalut et al., 2010; Serrano et al., 2012, 2013; Jiménez-Sánchez et al., 2013; Rodríguez-Rodríguez,2014). The post-LGM deglaciation was consistent with climate conditions in the Alps and Pyrenees (Ivy-Ochs et al., 2008; García-Ruiz et al., 2013, Jalut et al., 2010), with a Lateglacial cooling that formed glaciers only in the highest areas, and a short Late Holocene episode in the XIX century.

\section{Conclusions}

The last deglaciation of Cantabrian Mountain began after a local glacier maximum, represented by external moraines complexes of Brañagallones, Salgardas, Pido, Enol, Belbín, Vega del Naranco, Upper Carrión and Cardaño, El Valle or Espinosa de los Monteros, which occurred before $30 \mathrm{ka}$ ago. New dates obtained in the last few years support the model of a distinctive history for Cantabrian glaciers, consistent with the glacial evolution and deglaciation in the North Iberian Peninsula, Galician Mountain, Sanabria and the Pyrenees. This glaciation was followed by a moderate retreat during a short and less cold period. A new glacier advance, reaching a position close to the maximum extension of moraine complexes, took place at $22-18 \mathrm{ka} \mathrm{BP}$. It was a cold and very dry period related to European LGM.

After the second glacial stage there was an important deglaciation phase when ice disappeared of the lower massifs previously glaciated. Deglaciation occurred between 18 and 14 ka BP, with several equilibrium phases, when icefields disappeared and the main glaciers divided into minor tongues located in the upper part of valleys and slopes.

The Altitude stage implied a glacier growth dominated by topoclimatic factors in the massifs above 2100 meters, except in the highest massifs (Picos de Europa, Peña Prieta and Peña Ubiña), where glaciers developed in all orientations. The last glacier advances occurred necessarily later than $14 \mathrm{ka} \mathrm{BP}$, although only indirect local arguments point to the Younger Dryas. During this 'Lateglacial', rock glaciers developed, and there was noglacial activity below $2000 \mathrm{~m}$ a.s.l..

The proposed glacial timeline is essentially similar to the model established in the Central and Eastern Pyrenees for the old Upper Pleistocene glaciations (Jalut et al., 1992; García-Ruiz et al., 2003; Delmas, 2005), and the new scenarios with advances between 14-11.7 ka (Palacios et al., 2015). After $11 \mathrm{ka}$ the deglaciation was complete in the lowest massifs of Cantabrian Mountain and no evidences of glacial stages have been detected during most of the Holocene. Finally, new glacial features, mainly moraines, were built 
by glaciers in the Little Ice Age, which have decayed into present day icepatches. Only four small glaciers in historical times briefly occupied glacio-karstic cirques on the north-facing slopes of the highest peaks in Picos de Europa, disappearing at the end of the XIX century, when the Cantabrian Mountain was totally deglaciated.

\section{References}

Allen, J.R.M., Huntley, B., Watts,W.A. 1996. The vegetation and climate of northwest Iberia over the last 14000 yr. Journal of Quaternary Science 11 (2), 125-147.

Alonso-Herrero, E. 1987. Huellas del glaciarismo cuaternario en las cabeceras del río Esla, vertiente sur de la Cordillera Cantábrica (León). Cuaternario y Geomorfología 1, 49-59.

Alonso-Herrero, E. 2002. El glaciarismo en las cuencas altas de los ríos Esla y Porma. In El modelado de origen glaciar en las montañas leonesas, Redondo Vega, J.M., Gómez-Villar, A., González-Gutiérrez, R.B., Carrera Gómez, P. (coords.). Universidad de León, León, pp. 235-246.

Alonso Otero, F., Arenillas, M., Sáenz, C. 1982. La morfología glaciar en las Montañas de Castilla La Vieja y León. In I Congreso de Geografía de Castilla-León, Consejo General de Castilla y León, Burgos, pp. 23-41.

Álvarez-Lao, D.J., García, N. 2010. Chronological distribution of Pleistocene cold adapted large mammal faunas in the Iberian Peninsula.Quaternary International 212 (2), 120-128.

Álvarez-Lao, D.J., García, N. 2011. Geographical distribution of Pleistocene coldadapted large mammal faunas in the Iberian Peninsula. Quaternary International 233 (2), 159-170.

Arenillas, M., Alonso Otero, F. 1981. La morfología glaciar del Mampodre (León). Boletín de la Real Sociedad Española de Historia Natural, sección geológica 79 (3-4), 53-62.

Calvet, M., Delmas, M., Gunnell, Y., Braucher, R., Bourlès, D. 2011. Recent advances in research on Quaternary glaciations in the Pyrenees. In Quaternary Glaciations-Extent and Chronology. Developments in Quaternary Sciences 15, 127-139.

Carrión, J., Bañuls, S., López-García, J.M., Blain, H.A., Lozano, I. 2012. Paleoflora y Paleovegetacion de la Península Iberica e Islas Baleares: Plioceno-Cuaternario. Ministerio de Economía y Competitividad, Madrid.

Castañón, J.C. 1983. El glaciarismo cuaternario del Macizo de Ubiña (Asturias-León) y su importancia morfológica. Ería 4, 3-49.

Castañón, J.C., Frochoso, M. 1992. La glaciación Würm en las Montañas Cantábricas. In The Late Quaternary in the Western Pyrenean Region. C. Cearreta, F. Ugarte (eds.), Universidad del País Vasco, Bilbao, pp. 319-332.

Delmas, M. 2005. La déglaciation dans le massif du Carlit (Pyrénées orientales): approches géomorphologique et géochronologique nouvelles. Quaternaire 16 (1), 45-55.

Delmas, M., Gunnell, Y., Braucher, R., Calvet, M., Bourlès, D. 2008. Exposure age chronology of the last glaciation in the eastern Pyrenees. Quaternary Research 69 (2), 231-241.

Domínguez-Villar, D., Carrasco, R.M., Pedraza, J., Cheng, H., Edwards, R.L., Willenbring, J.K. 2013. Early maximum extent of paleoglaciers from Mediterranean mountains during the last glaciation. Scientific Reports 3, 2034, doi:10.1038/srep02034.

Frochoso, M. 1990.Geomorfología del Valle del Nansa. Servicio de Publicaciones de la Universidad de Cantabria, Santander.

Frochoso, M., Castañón, J.C. 1998. El relieve glaciar de la Cordillera Cantábrica. In Las huellas glaciares de las montañas españolas. A. Gómez-Ortiz, A. Pérez-Alberti (eds.), Universidade de Santiago de Compostela, Santiago de Compostela, pp. 65-138. 
Frochoso, M., González-Pellejero, R., Allende, F. 2013. Pleistocene glacial morphology and timing of Last Glacial Cycle in Cantabrian Mountains (Northern Spain): new chronological data from the Asón Area. Central Europe Journal of Geosciences 5 (1), 12-27.

Gale, S.J., Hoare, P.G. 1997. The glacial history of the Northwest Picos de Europa on Northern Spain. Zeitschrift für Geomorphologie 41, 81-96.

Gallinar, D., Ruiz-Fernández, J., Poblete, M.A., Fernández, A., García, C., Beato, S., Marino, J.L. 2014. Morfología y evolución glaciar en el sector asturiano del macizo de las Ubiñas. In Avances de la Geomorfología en España 2012-2014. S. Schnabel, Á. Gómez Gutiérrez (eds.), SEG-Universidad de Extremadura, Cáceres, pp. 543-547.

García-Ruiz, J.M., Valero, B.L., Martí-Bono, C., González-Sampériz, P. 2003. Asynchroneity of maximum glacier advances in the Central Spanish Pyrenees. Journal of Quaternary Science 18 (1), 61-72.

García-Ruiz, J.M., Moreno, A., González-Sampériz, P., Valero, B., Martí-Bono, C. 2010. La cronología del último ciclo glaciar en las montañas del sur de Europa. Una revisión. Cuaternario y Geomorfología 24 (1-2), 35-46.

García-Ruiz, J.M., Martí-Bono, C., Peña, J.L., Sancho, C., Rhodes, E.J., Valero, B., GonzálezSampériz, P., Moreno, A. 2013. Glacial and fluvial deposits in the Aragón Valley, centralwestern Pyrenees: chronology of the Pyrenean late Pleistocene glaciers. Geografiska Annaler 95A (1), 15-32.

Gómez-Lende, M., Berenger, F., Serrano, E. 2014. Morphology, ice types and thermal regime in a high mountain ice cave. First studies applying terrestrial laser scanner in The Peña Castil Ice Cave (Picos de Europa, Northern Spain). Geografia Fisica e Dinamique Quaternaria 37, 141-150.

Gómez-Villar, A., González-Gutiérrez, R.B., Redondo, J.M., Santos, J. 2011. Distribución de glaciares rocosos relictos en la Cordillera Cantábrica. Cuadernos de Investigación Geográfica37 (2), 49-80.

González-Amuchástegui, M.J. 2000. Evolución morfoclimática del País Vasco durante el Cuaternario: Estado de la cuestión. Cuaternario y Geomorfología 14 (3-4), 79-99.

González-Gutiérrez, R.B. 2002. El relieve de los valles del Torío y Curueño (Montaña Cantábrica Leonesa). Unpublished PhDThesis, Universidad de León, León.

González-Sampériz, P., Valero, B.L., Moreno, A., Jalut, G., García-Ruiz, J.M., Martí-Bono, C., Delgado, A., Navas, A., Otto, T., Dedoubat, J. 2006. Climate variability in the Spanish Pyrenees during the last 30,000 yr revealed by the El Portalet sequence. Quaternary Research 66 (1), 38-52.

González-Trueba, J.J. 2006. Topoclimatical factors and very small glaciers in Atlantic Mountain of SW Europe: The Little Ice Age glacier advance in Picos de Europa (NW Spain). Zeitschrift für Gletscherkunde und Glazialgeologie 39, 115-125.

González-Trueba, J.J. 2007a. El paisaje natural del Macizo Central de los Picos de Europa. CIMA, Consejería de Medio Ambiente, Santander.

González-Trueba, J.J. 2007b. La Pequeña Edad del Hielo en los Picos de Europa. Fundación Marcelino Botín, Santander.

González-Trueba, J.J., 2007c. Geomorfología del Macizo Central del Parque Nacional de Picos de Europa. OAPN-Ministerio de Medio Ambiente, Madrid.

González-Trueba, J.J., Martín-Moreno, R., Martínez de Pisón, E., Serrano, E. 2008. Little Ice Age glaciation and current glaciers in the Iberian Peninsula. The Holocene 18 (4), 551-568.

Hernández-Pacheco, F. 1944. Fisiografía, geología y glaciarismo cuaternario en las montañas de Reinosa. Memorias de la Real Academia de Ciencias Físicas Exactas y Naturales, Madrid. 
Hernández-Pacheco, F. 1961. La pequeña cuenca glaciar de la Peña Lusa en la Cordillera Cantábrica, Santander. Boletín Real Sociedad Española de Historia Natural, secc. Geología 59-2, 191-205.

Hughes, P.D., Woodward, J.C. 2008. Timing of glaciation in the Mediterranean mountains during the last cold stage. Journal of Quaternary Science 23 (6-7), 575-588.

Hughes, P.D., Woodward, J.C., Gibbard, P.L. 2006. Late Pleistocene glaciers and climate in the Mediterranean region. Global and Planetary Change 46, 83-98.

Ivy-Ochs, S., Kerschner, H., Reuther, A., Preusser, F., Heine, K., Maisch, M., Kubik, P.W., Schlüchter, C. 2008. Chronology of the last glacial cycle in the European Alps. Journal of Quaternary Science 23 (6-7), 559-573.

Jalut, G., Montserrat-Martí, J., Fontunge, M., Delibrias, G., Vilaplana, J., Julià, R. 1992. Glacial to interglacial vegetation changes in the northern and southern Pyrenees: deglaciation, vegetation cover and chronology. Quaternary Science Reviews 11, 449-480.

Jalut, G., Turu, V., Dedoubat, J.J., Otto, T., Ezquerra, J., Fontugne, M., Belet, J.M., Bonnet, L., García de Celis, G., Redondo, J.M., Vidal, J.R., Santos, J. 2010. Paleoenvironmental studies in NW Iberia (Cantabrian range): vegetation history and synthetic approach of the last deglaciation phases in the western Mediterranean. Palaeogeography, Palaeoclimatology and Palaeoecology 297, 330-350.

Jiménez-Sánchez, M. 1996. El glaciarismo en la cuenca alta del Río Nalón (NO de España): una propuesta de evolución de los sistemas glaciares cuaternarios en la Cordillera Cantábrica. Revista de la Sociedad Geológica de España 9 (3-4), 157-168.

Jiménez-Sánchez, M., Farias, P. 2002. New radiometric and geomorphologic evidence of Last Glacial maximum older than $18 \mathrm{ka}$ in SW European Mountains: the example of Redes Natural Park, Cantabrian Mountains. NW Spain. Geodinámica Acta 15 (1), 93-101.

Jiménez-Sánchez, M., Ruiz-Zapata, M.B., Farias, P., Dorado, M., Gil, M.J., Valdeolmillos, A. 2002. Palaeoenvironmental research in Cantabrian Mountains: Redes Natural Park and Comella basin. In Quaternary Climatic Changes and Environmental Crises in the Mediterranean Region. B. Ruiz, M. Dorado, A. Valdeolmillos, M.J. Gil, T. Bardají, I. Bustamante, I. Martínez (eds.), Universidad de Alcalá de Henares, Madrid, pp. 229-240.

Jiménez-Sánchez, M., Rodríguez-Rodríguez, L., García-Ruiz, J.M., Domínguez-Cuesta, M.J., Farias, P., Valero, B., Moreno, A., Rico, M., Valcárcel, M. 2013. A review of glacial geomorphology and chronology in northern Spain: timing and regional variability during the last glacial cycle. Geomorphology 196, 50-64.

Lotze, F. 1962. Überpleistozane Vergletscherungen in der Valnera Gruppe (ostliches Kantabrisches Gebirge). Neues Jahrbuch für Geologie und Paleontologie 7, 377-381.

Martínez de Pisón, E., Arenillas, M. 1979. Algunos problemas de morfología glaciar en la España Atlántica. Acta Geológica Hispánica 14, 445-450.

Martrat, B., Grimalt, J.O., Shackleton, N.J., De Abreu, L., Hutterli, M.A., Stocker, T.F. 2007. Four climate cycles of recurring deep and surface water destabilizations on the Iberian Margin. Science 317 (5837), 502-507.

Menéndez-Duarte, R., Marquínez, J. 1996. Glaciarismo y evolucióntardiglaciar de lasvertientes en el valle de Somiedo. CordilleraCantábrica. Cuaternario y Geomorfología 10 (3-4), 21-31.

Morales-Molino, C., García-Antón, M. 2014. Vegetation and fire history since the last glacial maximum in an inland area of the western Mediterranean Basin (Northern Iberian Plateau, NW Spain). Quaternary Research 81 (1), 63-77.

Morellón, M., Valero, B., González-Sampériz, P., Vegas, T., Rubio, E., Rieradevall, M., Delgado, A., Mata, P., Romero, O., Engstrom, D.R., López-Vicente, M., Navas, A., Soto, J. 2009. Climate changes and human activities recorded in the sediments of Lake Estanya (NE 
Spain) during the Medieval Warm Period and Little Ice Age. Journal of Paleolimnology 46 (3), 423-452.

Morellón, M., Pérez-Sanz, A., Corella, J.P., Büntgen, U., Catalán, J., González-Sampériz, P., González-Trueba, J.J., López-Sáez, J.A., Moreno, A., Pla, S., Saz, M.A., Scussolini, P., Serrano, E., Steinhilber, F., Stefanova, V., Vegas, T., Valero, B. 2012. A multi-proxy perspective on millennium-long climate variability in the Southern Pyrenees. Climate of The Past 8, 683-700.

Moreno, A., Valero, B.L., Jiménez-Sánchez, M., Domínguez-Cuesta, M.J., Mata, P., Navas, A., González-Sampériz, P., Stoll, H., Farias, P., Morellón, M., Corella, P., Rico, M. 2010. The last deglaciation in the Picos de Europa National Park (Cantabrian Mountains, northern Spain). Journal of Quaternary Science 25 (7), 1076-1091.

Moreno, A., López-Merino, L., Leira, M., Marco, J., González-Sampériz, P., Valero, B.L., LópezSáez, J.A., Santos, L., Mata, M.P., Ito, E. 2011. Revealing Holocene environmental history from multiproxy record of a mountain lake (Lago Enol, N Iberian Peninsula). Journal of Paleolimnology 46 (3), 327-349.

Muñoz Jiménez, J. 1980. Morfología estructural y glaciarismo en la Cordillera Cantábrica: el relieve del Sinclinal de Saliencia. Ería, 1, 35-65.

Muñoz-Sobrino, C., Ramil, P., Rodríguez-Guitián, M.A. 2001. Vegetation in the mountains of northwest Iberia during the last glacial-interglacial transition. Vegetation History and Archaeobotany 10, 7-21.

Muñoz-Sobrino, C., Ramil, P., Gómez-Orellana, L. 2004. Upper Würm and the Early Holocene in the mountains of NW Iberia: biostratigraphy, chronology and tree colonization. Polen 14, 524-525.

Muñoz-Sobrino, C.M., Ramil, P., Gómez-Orellana, L., Díaz-Varela, R.A. 2005. Palynological data on major Holocene climatic events in NW Iberia. Boreas 34 (3), 381-400.

Muñoz-Sobrino, C., Ramil, P., Gómez-Orellana, L. 2007. Late Würm and early Holocene in the mountains of northwest Iberia: biostratigraphy, chronology and tree colonization. Vegetation History and Archaeobotany 16 (4), 223-240.

Naughton, F., Sánchez-Goñi, M.F., Desprat, S., Turon, J.L., Duprat, J., Malaizé, B., Joli, C., Cortijo, E., Drago, T., Freitas, M.C. 2007. Present-day and past (last 25000 years) marine pollen signal off western Iberia. Marine Micropaleontology 62, 91-114.

Nieuwendam, A., Ruiz-Fernández, J., Oliva, M., Lopes, V., Cruces, A., Freitas, C. 2015. Postglacial evolution in Picos de Europa (Cantabrian Mountains, Northern Spain) based on geomorphological and micromorphological evidences of quartz grains. Permafrost and Periglacial Processes, accepted 02-Jan-2015.

Nussbaum, F., Cigax, F. 1952. La glaciation quaternarie dans la Cordilléere Cantabrique (Espagne du Nord). Revue Geographique des Pyréenées et du Sud-Ouest 23 (1), 36-48.

Obermaier, H. 1914. Estudio de los glaciares de los Picos de Europa. Trabajos del Museo Nacional de Ciencias Naturales: Serie Geológica 9, 1-42.

Oliveira, D. 2012. Vegetation response to Holocene climate variability in southwestern Europe. Ms thesis, Universidade de Lisboa, Faculdade de Ciencias, Departamento de Geología.

Palacios, D., De Marcos, J., Vázquez-Selem, L. 2011. Last glacial maximum and deglaciation of Sierra de Gredos, central Iberian Peninsula. Quaternary International 233 (1), 16-26.

Palacios, D., De Andrés, N., López-Moreno, J.I., García-Ruiz, J.M. 2015. Late Pleistocene deglaciation in the upper Gállego Valley, central Pyrenees. Quaternary Research doi. org/10.1016/ j.yqres.2015.01.010.

Pallàs, R., Rodés, A., Braucher, R., Carcaillet, J., Ortuño, M., Bordonau, J., Bourlès, D., Vilaplana, J.M., Massana, E., Santanach, P. 2007. Late Pleistocene and Holocene glaciation in the 
Pyrenees: A critical review and new evidence form ${ }^{10} \mathrm{Be}$ exposure ages, South Central Pyrenees. Quaternary Science Reviews 25 (21-22), 2937-2963.

Pellitero, R. 2011. El complejo morrénico de Vega de Naranco (León, Cordillera Cantábrica). Evolución y correlación de fases glaciares durante el último máximo glaciar. In $E l$ Cuaternario en España y áreas afines. Avances en 2011. V. Turu, A. Constante (eds.), Fundación Henri Chevalier, Andorra la Vella, pp. 7-9.

Pellitero, R. 2012. Geomorfología, paleoambiente cuaternario y geodiversidad en el macizo de Fuentes Carrionas Montaña Palentina. Unpublished PhD thesis. Universidad de Valladolid, Valladolid.

Pellitero, R. 2013. Evolución finicuaternaria del glaciarismo en el macizo de Fuentes Carrionas, (Cordillera Cantábrica), propuesta cronológica y paleoambiental. Cuaternario y Geomorfología 27 (1-2), 71-90.

Pellitero, R. 2014. Geomorphology and geomorphological landscapes of Fuentes Carrionas. Journal of Maps 10 (2), 313-323.

Pellitero, R., Serrano, E., González-Trueba, J.J. 2011. Glaciares rocosos del sector central de la Montaña Cantábrica: indicadores paleoambientales. Cuadernos de Investigación Geográfica 37 (2), 119-144.

Penck, A. 1897. Die Picos de Europa und das kantabrische Gebirge. Geographische Zeitschrift Leipzig, 278-281.

Pérez-Alberti, A., Rodríguez-Guitián, M., Valcárcel, M. 1992. El modelado glaciar en la vertiente oriental de la Sierra de Ancares (Noroeste de la Península Ibérica). Papeles de Geografía $18,39-51$.

Pérez-Alberti, A., Valcárcel, M., Martini, I.P. 2002. La deglaciación en la vertiente suroccidental del Macizo de Peña Trevinca (Montañas de Trevinca, NW Ibérico). In Estudios recientes (2000-2002) en Geomorfología, Patrimonio, Montaña, Dinámica Territorial. E. Serrano, A. García de Celis (eds.), SEG-Universidad de Valladolid. Valladolid, pp. 205-216.

Pérez-Obiol, R., Jalut, G., Julià, R., Pèlachs, A., Iriarte, M.J., Otto, T., Hernández-Beloqui, B. 2011. Mid-Holocene vegetation and climatic history of the Iberian Peninsula. The Holocene 21 (1), 75-93.

Redondo, J.M. 2002. El relieve glaciar de la sierra de Gistredo (NW de la Cordillera Cantábrica, León). In El modelado de origen glaciar en las montañas leonesas. Redondo, J.M., Gomez Villar, A., González Gutiérrez, R.B., Carrera, P. (coords.), Universidad de León, León, pp. 105-136.

Redondo, J.M., Gómez-Villar, A., González-Gutiérrez, R.B., Santos, J. 2010. Los glaciares rocosos de la Cordillera Cantábrica. Universidad de León, León.

Rico, I. 2011. Glacial morphology and evolution in the Arritzaga valley (Aralar range, Gipuzkoa). Cuaternario y Geomorfología, 25 (1-2), 83-104.

Rodríguez-Rodríguez, L., Jiménez-Sánchez, M., Domínguez-Cuesta, M.J., Aranburu, A. 2014. Research history on glacial geomorphology and geochronology of the Cantabrian Mountains, north Iberia (43-42 $\left.\mathrm{N} / 7-2^{\circ} \mathrm{W}\right)$. Quaternary International. Doi:10.1016/j.quaint. 2014.06.007.

Sáenz, C. 1935. Restos glaciares de Castro Valnera. Boletín Real Sociedad Española de Historia Natural 35, 236-237.

Slgueiro, E., Naughton, F., Voelker, A.H.L., De Abreu, L., Alberto, A., Rossignol, L., Duprat, J., Magalhâes, V.H., Vaqueiro, S., Turon, J.L., Arantes, F. 2014. Past circulation along the western Iberian margin: a time slice vision from the Last Glacial to the Holocene. Quaternary Science Reviews. Doi: 10.1016/j.quascirev.2014.09.001.

Santos, J. 2010. Glaciarismo y periglaciarismo en el Alto Sil, provincia de León (Cordillera Cantábrica). PhD thesis, Universidad de León. León. 
Santos, J., Redondo, J.M., González-Gutiérrez, R.B., Gómez-Villar, A. 2013. Applying the AABR method to reconstruct equilibrium-line altitudes from the last glacial maximum in the Cantabrian Mountains (SW Europe). Palaeogeography, Palaeoclimatology, Palaeoecology 387, 185-189.

Serrano, E., González Trueba, J.J. 2002. Morfología y evolución glaciar en los Picos de Europa. In El Modelado de Origen Glaciar en Las Montañas Leonesas. J.M. Redondo, A. Gómez Villar, R.S. González Gutiérrez, P. Carrera (coords.). Universidad de León, León, pp. 249268.

Serrano, E., Gutiérrez Morillo, A. 2002. El glaciarismo Pleistoceno en la vertiente meridional de la Cordillera Cantábrica (Montañas de Palencia, Cantabria y Burgos). In Geomorfología y Paisaje. Serrano, E., García de Celis, A. (eds.). Sociedad Española de GeomorfologíaUniversidad de Valladolid, Valladolid, pp. 91-161.

Serrano, E., González-Trueba, J.J., Sanjosé, J.J., Del Río, L.M. 2011. Ice patch origin, evolution and dynamics in a temperate high mountain environment: the Jou Negro, Picos de Europa (NW Spain). Geografiska Annaler 93 (2), 57-70.

Serrano, E., González-Trueba, J.J., González-García, M. 2012. Mountain glaciation and paleoclimate reconstruction in the Picos de Europa (Iberian Peninsula, SW Europe). Quaternary Research 78, 303-314.

Serrano, E., González-Trueba, J.J., Pellitero, R., González-García, M., Gómez-Lende, M. 2013. Quaternary glacial evolution in the Central Cantabrian Mountains (Northern Spain). Geomorphology 196, 65-82.

Serrano, E., Gómez-Lende, M., González-Amuchástegui, M., González-García, M., GonzálezTrueba, J.J., Pellitero, R., Rico, I. 2015. Glacial chronology, environmental changes and implications for human occupation during the upper Pleistocene in the eastern Cantabrian Mountains. Quaternary International 364, 22-34.

Smart, P.L. 1986. Origin and development of glacio-karst closed depressions in the Picos de Europa, Spain. Zeitschrift für Geomorphologie 30, 423-443.

Stoll, H.M., Moreno, A., Méndez, A., González-Lemos, S., Jiménez-Sánchez, M., DomínguezCuesta, M.J., Edwards, R.L., Cheng, H., Wang, X. 2014. Paleoclimate and growth rates of speleothems in the northwestern Iberian Peninsula over the last two glacial cycles. Quaternary Research 80 (2), 284-290.

Turu, V., Boulton, G.S., Ros, X., Peña, J.L., Matí-Bono, C.E., Bordonau, J., Serrano, E., Sancho, C., Constante, A., Pous, J., Gonzálkez-Trueba, J.J., Palomar, J., Herrero, R., García-Ruiz, J.M. 2007. Structure des grands bassins glaciaires dans le Nord de la péninsule ibérique: comparaison entre les vallées d'Andorre (Pyrénées Orientales), du Gállego (Pyrénées Centrales) et du Trueba (Chaîne cantabrique). Quáternaire 18 (4), 309-325.

Ugarte, F.M. 1992. Glacial and periglacial morphogenesis in the Basque mountains.In The Late Quaternary in the Western Pyrenean Region. Cearreta, A., Ugarte, F.(Eds.), Universidad del País Vasco, Bilbao, pp. 235-250.

Valcárcel, M., Pérez-Alberti, A. 2002. La glaciación finipleistocena en el sector noroccidental de las montañas leonesas: la Sierra de Ancares. In:El modelado de origen glaciar en las montañas leonesas. J.M. Redondo Vega,A. Gómez Villar,R.B. González Gutiérrez,P. Carrera Gómez (coords.). Universidad de León, León, pp. 67-102.

Vegas, J., Ruiz-Zapata, M.B., Ortiz, J.E., Galán, L., Torres, T.J., García-Cortés, A., Gil-García, M.J., Pérez-González, A., Gallardo, J.L. 2013. Identification of arid phases during the last 50kyrCal. ka BP from the Fuentillejo maarlacustrine record (Campo de Calatrava Volcanic Field, Spain). Journal of Quaternary Science 25 (7), 1051-1062. 